\title{
Does bank efficiency matter? Market value relevance of bank efficiency in Australia
}

\author{
Abul Shamsuddin ${ }^{\mathrm{a}}$ and Dong Xiang ${ }^{\mathrm{b}, *}$ \\ ${ }^{a}$ Newcastle Business School, University of Newcastle, Callaghan NSW 2308, Australia \\ ${ }^{\mathrm{b}}$ Department of Accounting, Finance and Economics, Griffith Business School, Griffith \\ University, Nathan QLD 4111, Australia
}

The stochastic frontier analysis is employed to investigate efficiency of publicly listed Australian banks over the period 1985 to 2008. The results suggest that technical, cost and profit efficiency of Australian banks have improved over time. Large banks have attained a higher level of cost efficiency but a lower level of technical efficiency compared to small banks. No substantial difference between the two groups is found in terms of profit efficiency. A panel regression of bank stock return on bank efficiency suggests that an improvement in technical, cost or profit efficiency contributes to the market value of a bank. Thus, the shareholder wealth maximization goal is aligned with the goal of maximizing bank efficiency in the Australian context.

\footnotetext{
*Corresponding author. Email: d.xiang@griffith.edu.au.
} 


\section{Introduction}

Since the deregulation of the Australian banking system a number of studies have investigated bank efficiency using the efficiency frontier analysis. One motivation behind these studies is that the stability of the banking system depends on the efficiency level of banks, as measured by a bank's ability to operate close to the best-practice frontier. The issue of bank efficiency has become more important following the Asian financial crisis and the subprime mortgage crisis and their widespread impact on the stability of the financial system. During both crises, the Australian banks demonstrated resilience to external shocks, which alludes to the fact that an economically efficient bank can withstand financial market turmoil better than its inefficient counterpart and can contribute more to the efficient allocation of capital and the stability of the financial system.

Financial deregulations undertaken between the early 1980s and the mid-1990s significantly contributed to the long-term health of the Australian banking sector. Over the period 1981 to 1988 , government controls over interest rates and the allocation of loan were gradually removed. The Government undertook measures aimed to increase competition in the financial services industry such as allowing foreign banks to operate in Australia, easing the process of establishing new domestic banks, selling public ownership in banks and insurance companies and the removal of restrictions on certain commercial activities so that banks can produce insurance and funds management products (Debelle and Kent, 1999). Increased competition in the credit market narrowed the spread between the standard variable mortgage rate and the official cash rate from 4.25 percentage points in 1993 to an average spread of around 1.80 over the decade to December 2007, which climbed back to 2.9 percentage points by April 2010 (Oliver, 2010). However, the declining interest rate spread after 1993 was not accompanied by decreasing profitability because of banks' ability to successfully exploit economies of scope and pricing flexibility in a deregulatory environment. The Australian banks have significantly diversified their asset and liability portfolios after the early 1990s and increased their reliance on non-interest income. This was partly grown out of their experience of worst losses in the early 1990s. At the early phase of financial deregulation, banks grew their balance sheets rapidly, favouring the corporate loan over the residential mortgage market. By 1989, the combination of high 
interest rates, corporate financial distress and a softening property market exposed the poor credit quality of the loan portfolio of Australian banks. Consequently, they incurred a total loss of nine billion dollars over 1990- 1991, which was 2.25\% of GDP in 1990 (Gizycki and Lowe, 2000).

In order to cope with the structural changes in the financial market in the post-deregulation period and to improve regulatory efficiency, the Wallis Inquiry (1997) recommended the formation of Australian Prudential Regulation Authority (APRA) with the responsibility of ensuring that financial institutions meet their obligations to customers. The responsibility for the prudential supervision of banks was taken over by the APRA from the Reserve Bank of Australia (RBA) in July 1998.

The objectives of our study are to measure technical, cost and profit efficiency of the publicly listed Australian banks over 1985 to 2008 - a period of considerable regulatory and structural changes in the banking sector, and to examine whether any improvement in bank efficiency contributes to bank shareholder wealth. Our study differs from previous Australian studies in the following ways.

First, both in terms of methodology and scope, our paper differs from the studies conducted by Avkiran (1999a and 1999b) and Sathye (2001). They use the Data Envelopment Analysis (DEA), which attributes any deviation from the best-practice frontier to inefficiency. Avkiran observes that bank inefficiency increases during the period of poor lending practices (1986 to 1991). More specifically, the average technical inefficiency level increases by 0.7 percent per year over 1986 to 1995, and for both regional and large banks, technical efficiency scores are just about the same. Sathye (2001) reports an average efficiency score of only 0.58 for 1996, which is much lower than the world average technical efficiency score of 0.86 for the corresponding circa (Berger and Humphrey, 1997). Kirkwood and Nahm (2006) do measure profit efficiency but use the DEA approach and employ a cost efficiency specification for modelling bank profit. They observe that the major banks have improved their profit efficiency between 1995 and 2002, while the regional banks have not experienced much change in efficiency. Unlike Avikran (1999a, and 1999b), Sathye (2001) and Kirkwood and Nahm (2006), we use the Stochastic Frontier Analysis (SFA) to measure efficiency, which attributes only a part of the deviation from the 
best-practice frontier to inefficiency. ${ }^{1}$ This paper evaluates technical, cost and profit efficiency of Australian banks over a long period, 1985 through 2008, allowing us to examine the time variation in efficiency during regulatory and structural changes in the banking system and corporate financial distress.

Second, unlike previous Australian studies, this paper uses the alternative profit function proposed by Berger and Mester (1997) to estimate profit efficiency scores. An alternative profit function is more realistic as it relaxes the assumptions of perfect competition in output pricing, ${ }^{2}$ the homogeneity in output quality and the complete flexibility in choosing any output scale or product mix. The standard profit function relates profit to input prices and output prices. On the other hand, the alternative profit function relates profit to input prices and output levels, making it free of potential measurement errors in output prices. An important goal of this study is to evaluate stock price relevance of bank efficiency. The sensitivity of bank stock returns with respect to technical, cost and profit efficiency is estimated to examine whether or not a change in the bank efficiency level is valued by market participants. Kirkwood and Nahm (2006) report a positive correlation between profit efficiency changes and stock price changes for Australian banks but their profit efficiency scores are derived from the DEA approach. ${ }^{3}$

This paper observes that over the sample span, technical, cost and profit efficiency of Australian banks have improved. In general, the Australian banks display a high level of cost and profit efficiency but a low level of technical efficiency. Compared to their regional counterparts, the big-four banks ${ }^{4}$ have a lower level of technical efficiency, but a higher level of cost and a similar level of profit efficiency. Essentially, the regional banks can achieve the same level of cost efficiency as that of the big-four banks by devising a better way of transforming inputs into outputs. Our findings seem to suggest that the big-four banks have gained economies of scope by taking advantages of financial deregulations to

\footnotetext{
${ }^{1}$ As Berger and Mester (1997) suggest that SFA has an advantage over DEA in terms of estimation of economic efficiency. Kempkes and Pohl (2010) also argue that the DEA technique may not be applicable to organizations with heterogeneous structure.

${ }^{2}$ Sturm and Williams $(2004,2008)$ find that major Australian banks use their market power as a barrier to entry to new foreign entrants.

${ }^{3}$ Some international studies (for example, Guzman and Reverte, 2008; Chu and Lim, 1998 and Beccalli et al., 2006) also observe that bank stock prices reflect DEA-based technical efficiency. In contrast to these studies, we derive efficiency scores from the SFA approach and examine the relation between different measures of efficiency (technical, cost and profit efficiency) and bank stock prices using a multi-factor model of stock returns.

${ }^{4}$ These are the Australian and New Zealand Banking Group Limited (ANZ), Commonwealth Bank of Australia (CBA), National Australia Bank (NAB), and Westpac Banking Corporation (WBC).
} 
expand their operations in the areas of fund management, insurance and financial planning services, and thereby improved both cost and profit efficiency. Each measure of bank efficiency is found to be positively associated with bank stock returns, confirming that bank efficiency is valued by equity market participants.

The rest of the article is organized as follows. Section II briefly introduces the models of bank efficiency and a multi-factor model of bank stock returns. Section III discusses the data, and the empirical results are presented in Section IV. Section V provides concluding comments.

\section{Empirical models}

This study employs a two-stage procedure for empirical analysis. In the first stage, technical, cost, and profit efficiency are assessed using the stochastic frontier analysis. In the second stage, a panel regression model is employed to examine the link between bank efficiency and bank stock returns.

\section{Technical efficiency model}

The SFA method was first proposed by Aigner et al. (1977) to estimate technical efficiency. This article uses a translog form of the stochastic frontier production function as it gives more flexibility in terms of the elasticity of substitution and scale properties compared to a Cobb-Douglas function. Banks typically produce multiple outputs using multiple inputs. A multiple-output production function can be formulated either as a system of equations or as a distance function (Shephard, 1970). In this study, we use an input-oriented translog distance function of the following form:

$$
\begin{aligned}
\ln d_{i t} & =\alpha+\sum_{n=1}^{3} \beta_{n} \ln x_{n i t}+\sum_{r=1}^{2} \chi_{r} \ln y_{r i t}+\frac{1}{2} \sum_{n=1}^{3} \sum_{m=1}^{3} \delta_{n m} \ln x_{n i t} \ln x_{m i t}+\frac{1}{2} \sum_{r=1}^{2} \sum_{s=1}^{2} \xi_{r s} \ln y_{r i t} \ln y_{s i t} \\
& +\sum_{n=1}^{3} \sum_{r=1}^{2} \phi_{n s} \ln x_{n i t} \ln y_{r i t}+\tau t+\frac{1}{2} \kappa t^{2}+\sum_{n=1}^{3} \psi_{n} t \ln x_{n i t}+\sum_{r=1}^{2} \theta_{m} t \ln y_{r i t}+v_{i t}
\end{aligned}
$$

where the term, $d_{i t}$ denotes the input distance, which takes a value greater than one; $x$ represents input and y represents output. So, $x_{n i t}$ is $\mathrm{n}$-th input of $\mathrm{i}$-th bank at time $t$ and $y_{\text {rit }}$ is $r$-th output of $i$-th bank at time $t$. In this study, the input variables are labour $\left(x_{1}\right)$, deposits and other borrowings $\left(x_{2}\right)$, and physical capital $\left(x_{3}\right)$; the outputs are loans $\left(y_{1}\right)$ including 
advances and other receivables, and non-interest bearing assets $\left(y_{2}\right){ }^{5} v_{\text {it }}$ is a random variable to account for errors of approximation and other sources of statistical noise in $d_{i t}$. Denoting $\mathrm{u}_{\mathrm{it}}$ as the inefficiency component, technical efficiency (TE) can be defined as $T E_{i t}=\exp \left(-u_{i t}\right)$. Since $T E_{i t}=d_{i t}^{-1}$ the inefficiency component can be expressed as $u_{i t}=\ln d_{i t}$. This function is non-decreasing, linearly homogeneous, and concave in inputs. Setting $\beta_{n} \geq 0$, $\ln d_{i t}=u_{i t}$ and $\beta_{1}+\beta_{2}+\beta_{3}=1$ equation (1) can be transformed as:

$$
\begin{aligned}
-\ln x_{1 i t}=\alpha+ & \sum_{n=1}^{2} \beta_{n} \ln \left(x_{n i t} / x_{1 i t}\right)+\sum_{r=1}^{2} \chi_{r} \ln y_{r i t}+\frac{1}{2} \sum_{n=1}^{2} \sum_{m=1}^{2} \delta_{n m}\left(\ln x_{n i t} / x_{1 i t}\right) \ln \left(x_{m i t} / x_{1 i t}\right) \\
& +\frac{1}{2} \sum_{r=1}^{2} \sum_{s=1}^{2} \xi_{r s} \ln y_{r i t} \ln y_{s i t}+\sum_{n=1}^{2} \sum_{r=R}^{2} \phi_{n r}\left(\ln x_{n i t} / x_{1 i t}\right) \ln y_{r i t}+\tau t+\frac{1}{2} \kappa t^{2} \\
& +\sum_{n=1}^{2} \psi_{n} t \ln \left(x_{n i t} / x_{1 i t}\right)+\sum_{r=1}^{2} \theta_{m} t \ln y_{r i t}+v_{i t}-u_{i t}
\end{aligned}
$$

The term, $u_{i t}$ in equation (2) is assumed to have an independent half-normal or truncatednormal distribution and takes the following form:

$u_{i t}=\eta_{i t} u_{i}=E X P(-\eta(t-T)) u_{i} ; t=1,2, \ldots, T$

where $T$ is the period number, and $u_{i t}$ is assumed to be independent and identically distributed with mean $\mu$ and variance $\sigma^{2}$. When $\eta$ is positive, negative, or equal to zero, the non-negative firm effect $u_{i t}$ decreases, increases, or remains constant as $t$ increases. Depending on assumptions about $\eta$ and $\mu$, the function can be viewed as a time-variant, normally distributed or a truncated distribution model (Battese and Coelli, 1992). Thus, the following four alternative modelling assumptions are examined to select a suitable model for empirical analysis:

1. Truncated distribution with a time-variant unrestricted model, where all parameters to be estimated;

2. Half-normal distribution with a time-variant model, $\mu=0$;

3. Truncated distribution with a time-invariant model, $\eta=0$; and

4. Half-normal distribution with a time-invariant model, $\mu=\eta=0$.

\footnotetext{
${ }^{5}$ For empirical analysis, noninterest income is used as a proxy for underlying noninterest bearing assets and off-balance sheet activities (for example, see Kirkwood and Nahm, 2006).
} 
The maximum-likelihood estimates of the parameters in Equation 2 are obtained using the program Frontier 4.1 (Coelli, 2007) under the assumption that $\sigma^{2}=\sigma_{v}^{2}+\sigma_{u}^{2}, \gamma=\sigma_{u}^{2} /\left(\sigma_{v}^{2}+\sigma_{u}^{2}\right){ }^{6}$ The term $\gamma$ lies between 0 and 1. A large value of $\gamma$ means that a large proportion of the noise component $(\sigma)$ arises from the inefficiency term, $\sigma_{u}$ rather than the random volatility term, $\sigma_{v}$. A likelihood ratio test at the $5 \%$ level of significance is conducted to test the null hypotheses put forward under Assumptions 1 to 4. The results suggest that Assumptions 1, 3 and 4 can be rejected. The null hypothesis of $\mu=0$ can not be rejected, which indicates that the error distribution is truncated at zero and the model has a time-varying efficiency component. That is, the inefficiency component in the distance function can be characterized by a half-normal distribution. Thus, the technical efficiency model under Assumption 2 is adopted to estimate technical efficiency scores. ${ }^{7}$

\section{Cost efficiency model}

Following the work of Berger and Mester (1997), a number of international studies applied the SFA approach to estimate both cost and profit efficiency (e.g. Yao et al, 2007; Kauko, 2009; Kasman and Turgutlu, 2009; Huang, Liao, and Chiang, 2010). This study uses Berger and Mester's (1997) approach to estimate the cost efficiency scores from the following translog cost function:

$$
\begin{aligned}
\ln T C_{i t}= & \alpha+\sum_{n=1}^{3} \beta_{n} \ln w_{n i t}+\sum_{r=1}^{2} \chi_{r} \ln y_{r i t}+\frac{1}{2} \sum_{n=1}^{3} \sum_{m=1}^{3} \delta_{n m} \ln w_{n i t} \ln w_{m i t}+\frac{1}{2} \sum_{r=1}^{2} \sum_{s=1}^{2} \xi_{r s} \ln y_{r i t} \ln y_{s i t} \\
& +\sum_{n=1}^{3} \sum_{r=1}^{2} \phi_{n r} \ln w_{n i t} \ln y_{r i t}+\tau t+\frac{1}{2} \kappa t^{2}+\sum_{n=1}^{3} \psi_{n} t \ln w_{n i t}+\sum_{r=1}^{2} \theta_{r} t \ln y_{r i t}+v_{i t}+u_{i t}
\end{aligned}
$$

This function must satisfy the properties of homogeneity of degree one in inputs and symmetry of the cross effects:

$$
\sum_{n=1}^{3} \beta_{n}=1, \sum_{n=1}^{3} \delta_{n m}=0, \sum_{n=1}^{3} \phi_{n r}=0, \delta_{n m}=\delta_{m n}, \xi_{r s}=\xi_{s r}
$$

where $T C_{i t}$ is the total cost, comprised of operating costs and interest expenses of the i-th bank at time $\mathrm{t} ; \mathrm{w}_{\mathrm{it}}$ and $y_{i t}$ are vectors of input prices and outputs for the $\mathrm{i}$-th bank, respectively; and $\exp \left(-u_{i t}\right)$ provides cost efficiency score of bank i in year t. In this model,

\footnotetext{
${ }^{6}$ The same software is also used to estimate the cost and profit frontier models.

${ }^{7}$ The detailed specification test results for the alternative assumptions regarding the stochastic frontier technical efficiency model are available from the corresponding author on request.
} 
the inputs are the price of labour $\left(w_{1}\right)$ measured as staff expenses divided by the number of staff, the price of deposits $\left(w_{2}\right)$ measured as interest expenses divided by total deposits, and the price of physical capital $\left(w_{3}\right)$ proxied by operating expenses minus staff expenses divided by fixed assets. The output variables are loans $\left(y_{1}\right)$ and non-interest bearing assets $\left(y_{2}\right)$. To satisfy linear homogeneity in input prices, total cost are normalized by the deposit price and to control for potential scale biases in estimation, equity capital (E) is also used as a normalizing variable. There are large differences in size among the Australian banks in terms of total assets and market capitalization. For example, in 2007, National Australia Bank (NAB) was 28 times larger than Bank of Queensland (BOQ) in assets, 35 times in profits, and 27 times in total expenses. Thus, large banks would have random errors with much larger variances in the absence of normalization. This difference would result in biases in estimation because the inefficiency term is derived from the composite residual and the variance of the inefficiency effects is dependent on bank size.

\section{Profit efficiency model}

As noted early, profit efficiency scores are calculated from an "alternative profit frontier" model of Berger and Mester (1997). The alternative profit frontier model uses the same translog specification and independent variables as the cost frontier model. The dependent variable in the translog profit function is $\ln \left(\mathrm{P}_{\mathrm{it}}+\theta\right)$, where $P_{i t}$ is the observed pre-tax profit of the $i$-th bank at time t. The use of pre-tax profit as a performance measure eliminates any apparent efficiency gain resulting from a bank's ability to manage its tax affairs. The term $\theta$ refers to the absolute value of the minimum level of profits over all the banks in a given year plus $1,\left|P_{\min }\right|+1$. The term $\theta$ is added to each bank's profit to ensure that all dependent variables are positive so that the natural $\log$ of profit can be taken (see Yildirim and Philippatos, 2007). The dependent variable $\ln \left(\mathrm{P}_{\mathrm{it}}+\theta\right)$ is normalized by the equity capital.

\section{Bank efficiency and stock returns}

Next, to investigate whether or not bank efficiency is valued by stock market participants, we use the standard market model augmented by the efficiency change variable and a bankspecific risk factor - the financial leverage ratio. Jensen and Meckling (1976) find that leverage affects agency costs, which arise from the separation of ownership and control in a professionally managed firm. Higher leverage increases financial risk exposure but can 
partly mitigate the agency problem. Thus, financial leverage is used as a control variable in the model. Therefore, the augmented market model can be expressed as follows:

$$
E R_{i t}=\alpha_{i}+\beta E M_{i t}+\lambda E C_{i t}+\psi L E_{i t}+e_{i t}
$$

where $E R_{i t}$ is excess return (over risk-free return) on bank stock $i$ in year $t ; E M_{i t}$ is excess return on the market portfolio; $E C_{i t}$ is the change in efficiency of $i$-th bank over time interval $(t-1, t)$; and $L E_{i t}$ is the degree of financial leverage, measured by the debt to equity ratio. The hypothesized sign of $\lambda$ is positive, implying that bank efficiency exerts a positive influence on bank stock performance.

\section{Data}

The sample includes an unbalanced panel data for ten domestic banks from 1985 to 2008 with a total of 190 usable bank-year observations. ${ }^{8}$ The data for the efficiency and the augmented market models are mainly collected from Datastream with the exception of data for staff numbers and salary expenses for certain years, which are collected from the annual reports of banks, and the KPMG Financial Institution Performance Surveys.

We employ the intermediation approach to examine the input-output relations. The input variables are labour $\left(x_{1}\right)$, deposits and other borrowings $\left(x_{2}\right)$, and physical capital $\left(x_{3}\right)$; the outputs are loans $\left(y_{1}\right)$ including advances, and other receivables, and noninterest bearing assets $\left(y_{2}\right)$. We use non-interest income as a proxy for noninterest bearing assets. Table 1 provides the data summary for the efficiency models for $2007 .{ }^{9}$ All financial variables are expressed in Australian dollars. The descriptive statistics show a high degree of crosssectional dispersion of equity capital, staff numbers, physical capital, deposits, loans, and profits due to the large market share of the big-four banks. This is evident from the share of big-four banks' inputs (outputs) in total inputs (outputs) of the banking industry. With respect to input prices, Macquarie Bank has the highest staff price and deposit price, reflecting its unique features as an investment bank. Suncorp Group has a very high price

\footnotetext{
${ }^{8}$ The sample includes the ANZ, CBA, NAB, WBC, the Bendigo Bank (BEN), Adelaide Bank (ADB), SuncorpMetway Group (SUN), St. George Bank (SGB), BOQ, and Macquarie Group (MQG). Due to data unavailability, the number of observations is not the same in all models, which is reported in the corresponding result tables.

${ }^{9}$ Since Adelaide Bank merged with the Bendigo Bank at the end of 2007, descriptive statistics for 2007 rather than 2008 are presented.
} 
for physical capital due to the fact that nonbanking operations such as insurance accounts for a large proportion of its financial services.

\section{INSERT TABLE 1 ABOUT HERE.}

In the market model, annual excess stock return is measured as the difference between stock return and risk-free return. Risk-free return is proxied by the yield on the Australian tenyear Treasury bond. The rate of return on the market portfolio is the rate of change in the Australia-DS Market return index constructed by Datastream. Annual stock returns include both price return and dividend yield. Due to lack of historical stock price data for some banks, the market model uses data from 1995 to 2008. Excess returns on bank stocks are averaged at $10.4 \%$ per annum over this period.

\section{Results and Discussions}

In general, the estimation results of the technical, cost and alternative profit frontier models are satisfactory in terms of goodness of fit. ${ }^{10}$ The likelihood ratio test confirms the overall statistical significance of all models at the $1 \%$ level. It is observed that 42 out of 69 model parameters are statistically significant with a $p$-value of $10 \%$ or less. The proportion of noise due to inefficiency is represented by gamma where $\gamma=\sigma_{u}^{2} /\left(\sigma_{v}^{2}+\sigma_{u}^{2}\right)$. The value of $\gamma$ is $64.3 \%$ for the technical efficiency model, $61.8 \%$ for the cost efficiency model and $28 \%$ for the profit efficiency model with a statistical significance level of $5 \%, 1 \%$, and $10 \%$, respectively. The time trend, $t$ has a positive effect in the total costs and profit frontier models but a negative effect on the production distance function. ${ }^{11}$ Thus, by introducing new technology, the banks incur higher costs and lower productivity but at the same time achieve higher profit.

\section{INSERT TABLE 2 ABOUT HERE}

\footnotetext{
${ }^{10}$ The detailed estimation results are available from the corresponding author on request.

11 The effect of time trend on an efficiency frontier is assessed by differentiating the distance production function, cost function or profit function with respect to time trend $t$.
} 


\section{Technical Efficiency Scores}

The estimated efficiency scores are presented in Table 2. Australian banks show a secular improvement in technical efficiency over the period 1985-2008. The average score of technical efficiency over the period is $84.5 \%$. This score is close to those of previous studies (see Sturm and Williams 2008). The incidence of inefficiency is more pronounced in earlier years and low technical efficiency scores are more prevalent among the big-four banks.

Over the whole sample span, the big-four banks have an average technical efficiency score of $82.2 \%$ while the regional banks have an average efficiency score of $89.4 \%$ (see Table 2). The Bank of Queensland, the smallest regional bank in the sample, had the highest technical efficiency score of $98.1 \%$. Technical efficiency scores under the stochastic frontier analysis are estimated based on the assumption of constant returns to scale. The estimated technical efficiency is the product of pure technical efficiency and scale efficiency. A number of previous studies find that the major banks, which mostly operate at the decreasing returns to scale, have inferior scale efficiency than the regional banks (Kirkwood and Nahm, 2006; and Neal, 2004). Thus, scale inefficiency could be the main contributor to the technical inefficiency of the major Australian banks. Furthermore, the regional banks are better at transforming inputs into outputs compared to the big-four banks. Total assets of the bigfour banks account for three-quarters of total assets in the Australian banking sector, providing them oligopolistic power in the market with an ability to operate under nonoptimal conditions. This is referred to as X-inefficiency by Leibenstein (1966). Thus, having dominant market power, the necessity of efficient transformation of inputs into outputs may not be as important for the big banks compared to the small banks.

\section{INSERT TABLE 2 ABOUT HERE.}

\section{Cost Efficiency Scores}

The average cost efficiency score for all banks over the period 1988-2008 is $91.2 \%$ with an annual growth rate of $0.2 \%$. The average cost efficiency score is $87.3 \%$ for regional banks and $94.4 \%$ for the big-four banks (see Table 2). ${ }^{12}$ Good performance of the big-four banks in terms of the cost efficiency may arise from the benefits of economies of scope, geographic diversification, access to a range of global funding sources and the notion of 'too-big-to-

\footnotetext{
${ }^{12}$ Note that the data are not available before 1988 for the big-four banks and before 1993 for the regional banks.
} 
fail.' The latter phenomenon could result in depositors charging lower premiums to the big banks for their deposits, hence lowering the banks' interest expenses (Grigorian and Manole, 2006). ${ }^{13}$ Increased competition due to deregulation also led to a decline in the size of domestic deposit-taking market and higher deposits costs for small banks with limited access to overseas funding sources.

An allocative efficiency score can be derived by dividing a cost efficiency score by the corresponding technical efficiency score (Coelli et al. 2005). The results for cost and technical efficiency implicitly suggest that allocative efficiency of Australian banks has declined over the period from 1988 to 2008. Allocative efficiency can be ascribed to an economically judicious combination of inputs and outputs achieved by the banks. The decrease in allocative efficiency is unexpected because deregulation usually fosters allocative efficiency of banks through increased competition. Also the removal of certain restrictions on the commercial activities allowed banks to provide insurance and fund management products, facilitating exploitation of potential economies of scope.

Furthermore, revenue growth rather than allocative efficiency may be a better means of improving the bank's bottom line. Over time, banks have increased the range of financial services they offer with additional convenience to customers. These services can increase revenues more than costs, resulting in a decline in allocative or cost efficiency but an improvement in profit efficiency (Berger and Mester, 2003).

\section{Profit Efficiency Scores}

Over the sample period 1988-2008, the average profit efficiency score for all banks is high at $91.1 \%$ (see Table 2). The big-four banks have an average profit efficiency score of $90.9 \%$ while the regional banks have an average profit efficiency score of $94.5 \%$. However, this profit efficiency gap has become smaller over time. From 2006 onwards, the big four banks have caught up or surpassed regional banks with respect to profit efficiency. By comparison, the cost efficiency of big four banks remained above that of regional banks,

\footnotetext{
${ }^{13}$ Similar practice is also observed by Choi and Elyasiani (2011) in the insurance industry, where many customers are inclined to buy insurance products from large insurers even at a higher price.
} 
which may have contributed to the significant improvement in profit efficiency of the bigfour banks. The rate of annual increase in profit efficiency of the big-four banks is higher than that of the regional banks over the sample span. This can be partly attributed to the fact that the big-four banks are better placed to take advantage of the innovation in financial products and electronic commerce compared to their regional counterparts.

\section{Market Model Results}

The augmented market model, as specified in Equation 5, is estimated using an unbalanced panel data set for ten banks over 14 years from 1995 through 2008, with total of 132 observations. First, panel unit root tests are conducted to determine whether the variables are nonstationary to avoid spurious regression. The Augmented Dickey-Fuller, PhillipsPerron, and Levin-Lin-Chu tests reject the null hypothesis of a unit root in the panel data for excess stock returns (ER), change in efficiency (EC), and excess market returns (EM). The null hypothesis of a unit root cannot be rejected at the 5\% level for the financial leverage (LE) variable. The first difference of LE is found to be stationary and therefore is used to estimate the model. To identify the appropriate empirical specification of the market model, we test the following restrictions: ${ }^{14}$

$\mathrm{H}_{1}$ : The model is a pooled model with the restrictions.

$\alpha_{i}=\alpha, \operatorname{Cov}\left(\mathrm{X}_{\mathrm{it}}, \mathrm{e}_{\mathrm{it}}\right)=0$

$\mathrm{H} 2$ : The model is a fixed effect model with the restrictions

$\alpha_{i} \neq \alpha_{j}, E\left(e_{i t} \mid \alpha_{i}, X_{i t}\right)=0 ; i, j=1,2,3, \ldots, 10$

H3: The model is a random effect model with the restrictions.

$\alpha_{i} \neq \alpha_{j}, \alpha_{i} \sim i i d\left(\alpha, \sigma^{2}\right) ; e_{i t} \sim i i d\left(0, \sigma^{2}\right) ; i, j=1,2,3, \ldots, 10$

where $\alpha$ is intercept; $e$ is the error term; $\sigma^{2}$ is variance of error term; and $\mathrm{X}$ is the vector of independent variables. The null hypothesis that alpha is a constant $\left(\mathrm{H}_{1}\right)$ can be rejected by an $F$-test at the 5\% significance level. A Hausman test is conducted to determine whether the model is a fixed effect model or a random effect model. The null hypothesis that the model is a random effect model $\left(\mathrm{H}_{3}\right)$ is rejected with a $p$-value of $1 \%$. Thus, a panel regression model with fixed effects is estimated under $\mathrm{H}_{2}$.

\footnotetext{
${ }^{14}$ Given our small sample, we have ruled out the possibility of allowing $\beta s$ to vary over time or across banks.
} 
The estimation results are reported in Table 3. An $F$-test shows that the model is significant at the $1 \%$ level. As expected, technical, cost, and profit efficiency all have a statistically significant positive effect on stock returns with a $p$-value of $1 \%$. This finding suggests that an improvement in any form of bank efficiency is perceived favourably by stock market participants. A bank's exposure to systematic risk is measured by beta, which lies between 0.775 and 0.783 , implying that the bank stock portfolio is slightly less risky than the market portfolio. The constant term $(\alpha)$ is positive for all models, which means the bank stock portfolio yields a positive abnormal return. The regression model with the profit efficiency change as a regressor has the smallest alpha of 0.881. By comparison, the model with the technical (cost) efficiency changes as a regressor has an alpha of 3.63 (6.47).

\section{INSERT TABLE 3 ABOUT HERE.}

The debt-equity ratio is a proxy for the degree of financial leverage. Table 3 shows that the coefficient of the debt-equity ratio is positive and significant at the $10 \%$ level in all three models. This fits well with the notion that the banks with higher financial leverage can generate more returns at the cost of higher financial risk exposure.

\section{Conclusions}

This paper is the first study that uses the stochastic frontier analysis (SFA) method to measure cost and profit efficiency of the Australian banks. This article estimates the technical, cost and profit efficiency scores for ten publicly listed Australian banks. Over the period from 1985 through 2008, bank efficiency has improved in Australia. In general, the Australian banks have a relatively low level of technical efficiency but a high level of cost and profit efficiency. Technological improvement is found to have a positive effect on profits but an adverse effect on costs.

Compared to their regional counterparts, the big-four banks have a lower level of technical efficiency but a higher level of cost efficiency. The low level of technical efficiency of the big-four banks is probably attributed to scale inefficiency. The big-four banks can employ market power as a barrier to new entrants, thus operate under decreasing returns to scale. The high level of cost efficiency of the big-four banks may also result from the implicit 
premium of being 'too big to fail'. By comparison, the regional banks may have to improve efficiency by devising a better way of transforming inputs into outputs to attain the same level of cost efficiency as that of the big-four banks.

At the second stage, a panel regression model is used to examine the link between bank efficiency and bank stock returns over the period 1995 to 2008. It is observed that technical, cost and profit efficiency have a positive effect on bank stock returns, implying that the goal of maximizing bank efficiency is aligned with the shareholder wealth maximization goal. 


\section{References}

Aigner, D., Lovell, C. A. K. and Schmidt, P. (1977) Formulation and estimation of stochastic frontier production function models, Journal of Econometrics, 6, 21-37.

Avkiran, N. (1999a) An application reference for Data Envelopment Analysis in branch banking: helping the novice researcher, International Journal of Bank Marketing, 17, 206-220.

Avkiran, N. (1999b) The evidence on efficiency gains: the role of mergers and the benefits to the public, Journal of Banking and Finance, 23, 991-1013.

Battese, G. E. and Coelli, T. J. (1992) Frontier production functions, technical efficiency and panel data: with application to paddy farmers in India, The Journal of Productivity Analysis, 3, 153-169.

Beccalli, E., Casu, B. and Girardone, C. (2006) Efficiency and stock performance in European banking, Journal of Business Finance \& Accounting, 33, 245-262.

Berger, A and Humphrey, D. (1997), Efficiency of Financial Institutions: International survey and directions for future research, European Journal of Operational Research, 98, 175-212.

Berger, A. N. and Mester, L. (1997) Inside the black box: what explains differences in the efficiencies of financial institutions? Journal of Banking and Finance, 21, 895-947.

Berger, A. N. and Mester, L. (2003) Explaining the dramatic changes in performance of US banks: technological change, deregulation, and dynamic changes in competition, Journal of Financial Intermediation, 12, 57-95.

Choi, B. P. and Elyasiani, E. (2011) Foreign-owned insurer performance in the US property-liability markets, Applied Economics, 43, 291-306.

Chu, S.F. and Lim, G.H. (1998) Share performance and profit efficiency of banks in an Oligopolistic market: evidence from Singapore, Journal of Multinational Financial Management, 8, 155-168.

Coelli, T. J. (2007) A guide to Frontier version 4.1: a computer program for stochastic frontier production and cost function estimation, Centre for Efficiency and Productivity Analysis, Working Paper 96/07, Department of Econometrics, University of New England, Australia.

Coelli, T. J., Rao, D. S. P., O’Donnell, C. J. and Battese, G. E. (2005) An introduction to efficiency and productivity analysis, 2nd edn, Kluwer Academic Publishers, Boston. 
Debelle, G. and Kent, C. (1999) Trends in the Australian banking system: implication for financial system stability and monetary policy, RBA Research Discussion Papers, PDP 1999-05.

Gizycki, M. and Lowe, P. (2000) The Australian financial system in the 1990s, in proceedings of the Australian Economy in the 1990s, Reserve Bank of Australia, Sydney, pp.180-215.

Grigorian, D. A. and Manole, V. (2006) Determinants of commercial bank performance in transition: an application of data envelopment analysis, Comparative Economic Studies, 48, 497-522.

Guzman, I. and Reverte, C. (2008) Productivity and efficiency change and shareholder value: evidence from the Spainish banking sector, Applied Economics, 40, 2033-2040.

Huang, T. H., Liao, Y. T. and Chiang, L. C. (2010) An examination on the cost efficiency of the banking industry under multiple output prices' uncertainty, Applied Economics, 42, 1169-1182.

Jensen, M. and Meckling, W. (1976) Theory of the firm: managerial behavior, agency costs and capital structure, Journal of Financial Economics, 3, 305-360.

Kasman, A. and Turgutlu, E. (2009) Cost efficiency and scale economies in the Turkish insurance industry, Applied Economics, 41, 3151-3159.

Kauko, K. (2009) Manager and efficiency in banking, Journal of Banking and Finance, 33, 546-556.

Kempkes, G. and Pohl, C. (2010) The effect of German universities-some evidence from nonparametric and parametric methods, Applied Economics, 42, 2063-2079.

Kirkwood, J. and Nahm, D. (2006) Australian banking efficiency and its relation to stock returns, The Economic Record, 82, 253-267.

Leibenstein, H. (1966) Allocative efficiency vs. 'X-efficiency', American Economic Review, 56, 392-415.

Neal, P. (2004) X-efficiency and productivity change in Australian banking, Australian Economic Papers, 43, 174-191.

Oliver, S. (2010) How high will the Australian cash rate go?, available at http://www.ampcapital.com/ (accessed 5 September 2010).

Sathye, M. (2001) X-efficiency in Australian banking: an empirical investigation, Journal of Banking and Finance, 25, 613-630.

Shephard, R. W. (1970) The theory of cost and production functions, Princeton University Press, Princeton. 
Sturm, J.E. and Williams, B. (2004) Foreign bank entry, deregulation and bank efficiency: lessons from the Australian experience, Journal of Banking and Finance, 28, 17751799.

Sturm, J. E. and Williams, B. (2008) Characteristics determining the efficiency of foreign banks in Australia, Journal of Banking and Finance, 32, 2346-2360.

Wallis Inquiry (1997) Financial System Inquiry, Australian Government Publishing Service, Canberra.

Yao, S., Jiang, C., Feng, G. and Willenbockel, D. (2007) WTO changes and efficiency of Chinese banks, Applied Economics, 39, 629-643.

Yildirim, H. S. and Philippatos, G. C. (2007) Efficiency of banks: recent evidence from the transition economies of Europe 1993-2000, The European Journal of Finance, 13, 123 143. 
Table 1. Descriptive statistics of variables employed in the production distance, cost and profit functions, 2007

\begin{tabular}{|c|c|c|c|c|c|c|c|}
\hline Symbol & Definition & \multicolumn{2}{|c|}{ Large banks } & \multicolumn{2}{|c|}{ Small banks } & \multicolumn{2}{|c|}{ All banks } \\
\hline $\begin{array}{l}\text { Dependent } \\
\text { variables }\end{array}$ & & Mean & Std. dev & Mean & Std. dev & Mean & Std. dev \\
\hline $\mathrm{TC}$ & $\begin{array}{l}\text { Total cost: Comprises } \\
\text { operating costs and interest } \\
\text { expenses (billion } \$ \text { ) }\end{array}$ & 26.482 & 6.573 & 4.851 & 3.802 & 13.501 & 12.129 \\
\hline $\mathrm{P}$ & Pre-tax profits (billion\$) & 6.283 & 1.182 & 0.943 & 0.861 & 3.076 & 2.912 \\
\hline \multicolumn{8}{|c|}{ Input quantities } \\
\hline $\mathrm{x} 1$ & $\begin{array}{l}\text { Full-time equivalent staff } \\
\text { number }\left(000^{\prime}\right)\end{array}$ & 34.773 & 4.242 & 6.513 & 6.103 & 17.813 & 15.542 \\
\hline $\mathrm{x} 2$ & $\begin{array}{l}\text { Deposits and other borrowings } \\
\text { (billion\$) }\end{array}$ & 212.823 & 21.632 & 25.713 & 21.553 & 100.562 & 98.741 \\
\hline $\mathrm{x} 3$ & Physical capital (billion\$) & 1.343 & 0.623 & 0.192 & 0.174 & 0.652 & 0.703 \\
\hline \multicolumn{8}{|l|}{ Input prices } \\
\hline w1 & Price of labour & 93.130 & 10.831 & 135.002 & 117.492 & 118.254 & 90.420 \\
\hline w2 & Price of deposits & 0.085 & 0.005 & 0.121 & 0.097 & 0.107 & 0.075 \\
\hline w3 & Price of physical capital & 3.837 & 1.674 & 6.079 & 5.038 & 5.182 & 4.047 \\
\hline \multicolumn{8}{|l|}{$\begin{array}{l}\text { Output } \\
\text { quantities }\end{array}$} \\
\hline y1 & Loans (billion\$) & 302.702 & 30.113 & 40.513 & 27.962 & 145.383 & 138.092 \\
\hline y2 & Noninterest income (billion\$) & 6.883 & 4.363 & 2.112 & 2.744 & 4.023 & 4.073 \\
\hline \multicolumn{8}{|l|}{$\begin{array}{l}\text { Normalizing } \\
\text { Variable }\end{array}$} \\
\hline $\mathrm{E}$ & Equity capital (billion\$) & 21.324 & 3.973 & 4.414 & 4.632 & 11.177 & 9.664 \\
\hline
\end{tabular}


Table 2. Efficiency scores for Australian banks, 1985-2008*

\begin{tabular}{|c|c|c|c|c|c|c|c|c|c|}
\hline & \multicolumn{3}{|c|}{ Large banks } & \multicolumn{3}{|c|}{ Small banks } & \multicolumn{3}{|c|}{ All banks } \\
\hline Year & $\begin{array}{c}\text { Technical } \\
\text { efficienc } \\
y \\
\end{array}$ & $\begin{array}{c}\text { Cost } \\
\text { efficienc } \\
\mathrm{y} \\
\end{array}$ & $\begin{array}{c}\begin{array}{l}\text { Profit } \\
\text { efficienc } \\
\mathrm{y}\end{array} \\
\end{array}$ & $\begin{array}{c}\text { Technical } \\
\text { efficienc } \\
y\end{array}$ & $\begin{array}{c}\text { Cost } \\
\text { efficienc } \\
\mathrm{y} \\
\end{array}$ & $\begin{array}{c}\begin{array}{l}\text { Profit } \\
\text { efficienc } \\
\mathrm{y}\end{array} \\
\end{array}$ & $\begin{array}{c}\text { Technical } \\
\text { efficienc } \\
y \\
\end{array}$ & $\begin{array}{c}\text { Cost } \\
\text { efficienc } \\
\mathrm{y} \\
\end{array}$ & $\begin{array}{c}\begin{array}{c}\text { Profit } \\
\text { efficien } \\
\text { cy }\end{array} \\
\end{array}$ \\
\hline 1985 & 0.789 & & & & & & 0.789 & & \\
\hline 1986 & 0.796 & & & & & & 0.796 & & \\
\hline 1987 & 0.802 & & & & & & 0.802 & & \\
\hline 1988 & 0.770 & 0.933 & 0.773 & & & & 0.770 & 0.933 & 0.773 \\
\hline 1989 & 0.776 & 0.934 & 0.796 & 0.931 & & & 0.807 & 0.934 & 0.796 \\
\hline 1990 & 0.782 & 0.935 & 0.817 & 0.934 & & & 0.812 & 0.935 & 0.817 \\
\hline 1991 & 0.789 & 0.937 & 0.836 & 0.898 & & & 0.825 & 0.937 & 0.836 \\
\hline 1992 & 0.795 & 0.938 & 0.853 & 0.901 & & & 0.830 & 0.938 & 0.853 \\
\hline 1993 & 0.801 & 0.939 & 0.869 & 0.904 & 0.899 & 0.943 & 0.835 & 0.931 & 0.884 \\
\hline 1994 & 0.806 & 0.940 & 0.884 & 0.930 & 0.868 & 0.906 & 0.860 & 0.909 & 0.893 \\
\hline 1995 & 0.812 & 0.941 & 0.897 & 0.866 & 0.856 & 0.898 & 0.844 & 0.890 & 0.898 \\
\hline 1996 & 0.818 & 0.942 & 0.908 & 0.870 & 0.858 & 0.910 & 0.849 & 0.892 & 0.909 \\
\hline 1997 & 0.823 & 0.944 & 0.919 & 0.873 & 0.861 & 0.920 & 0.853 & 0.894 & 0.920 \\
\hline 1998 & 0.828 & 0.945 & 0.928 & 0.877 & 0.863 & 0.929 & 0.858 & 0.896 & 0.929 \\
\hline 1999 & 0.833 & 0.946 & 0.936 & 0.881 & 0.866 & 0.938 & 0.862 & 0.898 & 0.937 \\
\hline 2000 & 0.838 & 0.947 & 0.944 & 0.884 & 0.868 & 0.945 & 0.866 & 0.900 & 0.945 \\
\hline 2001 & 0.843 & 0.948 & 0.950 & 0.888 & 0.871 & 0.951 & 0.870 & 0.902 & 0.951 \\
\hline 2002 & 0.848 & 0.949 & 0.956 & 0.891 & 0.873 & 0.957 & 0.874 & 0.903 & 0.957 \\
\hline 2003 & 0.852 & 0.950 & 0.961 & 0.894 & 0.876 & 0.962 & 0.877 & 0.905 & 0.962 \\
\hline 2004 & 0.857 & 0.951 & 0.966 & 0.897 & 0.878 & 0.967 & 0.881 & 0.907 & 0.967 \\
\hline 2005 & 0.861 & 0.952 & 0.970 & 0.900 & 0.880 & 0.971 & 0.885 & 0.909 & 0.971 \\
\hline 2006 & 0.865 & 0.953 & 0.974 & 0.903 & 0.882 & 0.974 & 0.888 & 0.910 & 0.974 \\
\hline 2007 & 0.869 & 0.954 & 0.977 & 0.906 & 0.885 & 0.977 & 0.891 & 0.912 & 0.977 \\
\hline 2008 & 0.873 & 0.955 & 0.980 & 0.845 & 0.881 & 0.973 & 0.861 & 0.923 & 0.977 \\
\hline Mean & 0.822 & 0.944 & 0.909 & 0.894 & 0.873 & 0.945 & 0.845 & 0.912 & 0.911 \\
\hline AEC\# & 0.006 & 0.001 & 0.010 & 0.003 & 0.002 & 0.007 & 0.004 & 0.002 & 0.008 \\
\hline
\end{tabular}

*Efficiency scores for certain years are unavailable due to data constraint. \#AEC denotes average efficiency change. 
Table 3. Augmented market model results, 1996-2008

\begin{tabular}{|c|c|c|c|c|c|c|c|c|c|c|c|c|}
\hline & \multicolumn{4}{|c|}{$\begin{array}{c}\text { Model } \\
\text { with technical efficiency change }\end{array}$} & \multicolumn{4}{|c|}{$\begin{array}{c}\text { Model } \\
\text { with cost efficiency change }\end{array}$} & \multicolumn{4}{|c|}{$\begin{array}{c}\text { Model } \\
\text { with profit efficiency change }\end{array}$} \\
\hline & Constant & $\begin{array}{c}\text { Change } \\
\text { in } \\
\text { TE }\end{array}$ & EM & $\begin{array}{c}\text { Change } \\
\text { in } \\
\text { LE }\end{array}$ & Constant & $\begin{array}{c}\text { Change } \\
\text { in } \\
\text { CE }\end{array}$ & EM & $\begin{array}{c}\text { Change } \\
\text { in } \\
\text { LE }\end{array}$ & Constant & $\begin{array}{c}\text { Change } \\
\text { in } \\
\text { PE }\end{array}$ & EM & $\begin{array}{c}\text { Change } \\
\text { in } \\
\text { LE }\end{array}$ \\
\hline Coe. & 3.631 & 0.612 & 0.783 & 0.012 & 6.473 & 0.964 & 0.775 & 0.013 & 0.881 & 0.148 & 0.778 & 0.013 \\
\hline p-value & 0.000 & 0.000 & 0.000 & 0.100 & 0.000 & 0.000 & 0.000 & 0.076 & 0.000 & 0.000 & 0.000 & 0.085 \\
\hline \multicolumn{13}{|l|}{$\begin{array}{l}\text { Fixed } \\
\text { Effect }\end{array}$} \\
\hline ANZ & \multicolumn{4}{|c|}{-0.236} & \multicolumn{4}{|c|}{0.867} & \multicolumn{4}{|c|}{0.218} \\
\hline CBA & \multicolumn{4}{|c|}{-0.485} & \multicolumn{4}{|c|}{-0.615} & \multicolumn{4}{|c|}{0.024} \\
\hline NAB & \multicolumn{4}{|c|}{-0.220} & \multicolumn{4}{|c|}{0.753} & \multicolumn{4}{|c|}{-0.064} \\
\hline WBC & \multicolumn{4}{|c|}{-0.049} & \multicolumn{4}{|c|}{1.141} & \multicolumn{4}{|c|}{-0.155} \\
\hline BEN & \multicolumn{4}{|c|}{-0.411} & \multicolumn{4}{|c|}{-1.249} & \multicolumn{4}{|c|}{-0.071} \\
\hline $\mathrm{ADB}$ & \multicolumn{4}{|c|}{0.591} & \multicolumn{4}{|c|}{-0.417} & \multicolumn{4}{|c|}{-0.075} \\
\hline SUN & \multicolumn{4}{|c|}{0.452} & \multicolumn{4}{|c|}{-0.197} & \multicolumn{4}{|c|}{0.127} \\
\hline SGB & \multicolumn{4}{|c|}{-0.002} & \multicolumn{4}{|c|}{-0.150} & \multicolumn{4}{|c|}{-0.081} \\
\hline BOQ & \multicolumn{4}{|c|}{0.978} & \multicolumn{4}{|c|}{-0.915} & \multicolumn{4}{|c|}{0.050} \\
\hline MQG & \multicolumn{4}{|c|}{-0.489} & & 0.6 & & & & 0.0 & & \\
\hline Ad- $R^{2}$ & & 0.5 & & & & $\overline{0.6}$ & & & & 0.6 & & \\
\hline $\mathrm{F}$ & & 17.1 & & & & 17. & & & & 17.8 & & \\
\hline Pr-F & & 0.0 & & & & 0.0 & & & & 0.0 & & \\
\hline D.W & & 2.19 & & & & 2.2 & & & & 2.2 & & \\
\hline $\mathrm{N}$ & & 13 & & & & 1. & & & & 13 & & \\
\hline
\end{tabular}

Notes: Dependent variable is annual excess return on bank stocks. TE, CE, and PE are technical efficiency, cost efficiency, and profit efficiency scores, respectively; EM is excess return on the market portfolio; LE is financial leverage. The sample includes ten Australian banks: ANZ, CBA, NAB, WBC, BEN, ADB, SUN, SGB, BOQ and MQG. 